\title{
Effect of Daminozide, Chlormequat Chloride and Ethephon on Tanier (Xanthosoma caracu Koch \& Bouché) Yield and Yield Components'
}

\author{
A. J. Beale and V. E. Green, Jr. ${ }^{2}$
}

ABSTRACT

\begin{abstract}
The effects of foliar applications of daminozide (Alar), chlormequat chloride (Cycocel) and ethephon (Ethrel) on tanier (Xanthosoma caracu Koch \& Bouché) yield and yield components were determined. Cycocel-treated plants developed more foliage and foliage of a darker green than the control 2.5 months after application. No significant differences in yield, in cormel size, or in number of cormels per ha were found among the treatments.
\end{abstract}

\section{INTRODUCTION}

Tanier (Xanthosoma caracu Koch \& Bouché) is the second most important root crop in Puerto Rico, worth $\$ 4.8$ million in the 1977-78 season (2). It was worth $\$ 12$ million in Florida during the same period (8). It is a staple of the people of the Caribbean and of western Africa (1).

The tanier plant is not efficient in the translocation of photosynthates to produce secondary cormels. It produces leaves which have no direct effect on cormel production. Karikari (7) showed that up to four leaves could be removed per plant without affecting yield. In other root crops, it has been shown that large amounts of foliage are not related to high yields. Williams (9) found that in cassava, the highest yielding variety tested had the lowest leaf area index and vice versa. The manipulation of the tanier plant to promote cormel initiation and development at the expense of other plant parts would lead to a yield increase.

Chlormequat chloride (Cycocel), ${ }^{3}$ when foliarly sprayed, has induced tuberization and increased the yield of potato and sweet potato (3). Humphries (5) found that treatment with Cycocel and leaf longevity were positively correlated. Unlike in mustard, Cycocel did not decrease the net assimilation rate in sugar beet (6), possibly because the root provides a large photosynthetic sink. Perhaps the same mechanism operates in taniers. Ethephon (Ethrel) ${ }^{4}$ could help overcome apical dominance lead-

\footnotetext{
${ }^{1}$ Submitted to Editorial Board October 14, 1980. advisory committee.

${ }^{3} 2$ echloroethyltrimethyl ammonium chloride.

${ }^{4}$ 2-chloroethylphosphonic acid.
}

${ }^{2}$ Assistant Agronomist, Agricultural Experiment Station, University of Puerto Rico, Río Piedras, P.R.; Professor (Agronomist), Institute of Food and Agricultural Sciences, University of Florida, Gainesville, Fla. This work was supported by the Agricultural Experiment Station of the University of Puerto Rico and the University of Florida and was submitted by the senior author as a portion of his dissertation in partial fulfillment of the requirements for the degree of Doctor of Philosophy. The second author was chairmain of his graduate 
ing to the initiation and development of branches or secondary cormels. In addition, it could promote maturity of the plant, resulting in a slower rate of leaf production and in the translocation of nutrient elements and photosynthate from the leaves to the main and secondary cormels. Groskopp ${ }^{5}$ reported that foliar sprays of daminozide (Alar) ${ }^{6}$ at 1.12 or 2.24 $\mathrm{kg} / \mathrm{ha}$ resulted in a decrease in the number of large "Russet Burbank" potato tubers. However, none of the treatments resulted in an increase of tubers per plant. Alar is generally used to increase branching, stop vegetative growth, and promote leaf duration.

\section{MATERIALS AND METHODS}

Two non-replicated exploratory trials and one replicated experiment were carried out to determine the effects of the foliar application of growth regulators at different stages of plant growth on vegetative characters, yield and yield components. All treatments in the trials and in the experiment were applied in aqueous solution through a pressurized hand sprayer at $2.11 \mathrm{~kg} / \mathrm{cm}^{2}$ pressure of $\mathrm{CO}_{2}$ gas.

TABLE 1.-Description of two growth regulator trials and one experiment

\begin{tabular}{llclc}
\hline $\begin{array}{c}\text { Trial or ex- } \\
\text { periment } \\
\text { number }\end{array}$ & Planting date & $\begin{array}{c}\text { Plant age at } \\
\text { treatment ap- } \\
\text { plication }\end{array}$ & Soil ${ }^{1}$ type & Plot size \\
\hline Trial 1 & February, 1976 & Months & Rockland & $1.2 \times 15.2$ \\
Trial 2 & June 26, 1976 & 6 & Perrine marl & $3.7 \times 30.5$ \\
Experiment 1 & April 10, 1977 & $71 / 2,81 / 4,9$ & Rockland & $4.8 \times 12.2$ \\
\hline
\end{tabular}

${ }^{1}$ According to Gallatin et al. (4).

Planting distance was $1.2 \mathrm{~m}$ between rows and $0.6 \mathrm{~m}$ within the row. Table 1 shows the planting date, plant age at the date of treatment application, soil type and experimental plot size. A distance of $2.4 \mathrm{~m}$ was left between the treated experimental rows both in trial 1 and in experiment 1; and a distance of $4.8 \mathrm{~m}$ was left between the treated experimental rows in trial 2 in order to avoid contamination due to drift. The cultivar used in both trials and in the experiment is known in Florida as Santo Domingo White.

The treatments in trial 1 were $1,500,3,000$, and $6,000 \mathrm{p} / \mathrm{m}$ Alar; 1,000 , 2,000, and 4,000 p/m Cycocel; 1,000, 2,000 and 4,000 p/m Ethrel; and a water check. Treatments were applied in one liter of water in trial 1,2 liters in trial 2 , and 4 liters per plot in experiment 1 . Wex, a wetting agent was used at $10 \mathrm{ml}$ per 6 liters of water in both applications in trial 2 , and at $5 \mathrm{ml}$ in the first application, and at $2 \mathrm{ml}$ per 4 liters of water in the

${ }^{5}$ Groskopp, M. D. 1973. Personal Communication.

${ }^{6}$ Butanedioic acid mono (2,2-dimethylhydrazide). 
second and third applications of experiment 1. Tables 2 and 3 show the treatments in trial 2 and in experiment 1.

Standard planting and crop production practices were followed in the trials and in the experiment. Irrigation was provided about once a month in trial 1 and experiment 1 , and more often in trial 2 . The soil type in trial 1 and experiment 1 is a Rockland (4). It is formed of Miami oolite or Tamiami limestone that has a very shallow covering of unconsolidated soil material in places but which does not have enough soil material to be classified as a true soil. The soil in trial 2 is a hyperthermic, carbonatic,

TABLE 2.-Effect of the foliar application of growth regulators on yield in replicated trial 2

\begin{tabular}{|c|c|c|c|c|c|}
\hline \multirow{2}{*}{$\begin{array}{l}\text { Growth } \\
\text { regulator }\end{array}$} & \multicolumn{2}{|c|}{$\begin{array}{l}\text { Concentration-months } \\
\text { from planting }\end{array}$} & \multirow{2}{*}{ Yield } & \multirow{2}{*}{ No. of cormels/ha } & \multirow{2}{*}{$\begin{array}{l}\text { Mean weight/cor } \\
\text { mel }\end{array}$} \\
\hline & 9 & 10 & & & \\
\hline & $p / m$ & $p / m$ & t/ha & $10^{3}$ & $g$ \\
\hline Ethephon & 4000 & 4000 & 22.34 & 92.3 & 242 \\
\hline Cycocel & 4000 & 4000 & 22.90 & 96.4 & 238 \\
\hline Alar & 4000 & 4000 & 22.50 & 108.0 & 208 \\
\hline $\mathrm{GA}_{3}$ & 0 & 400 & 22.41 & 98,2 & 228 \\
\hline Control & 0 & 0 & 23.10 & 113.3 & 204 \\
\hline
\end{tabular}

${ }^{1}$ Planted June 26, 1976 and harvested July 1, 1977.

TABLE 3.-Effect of the foliar application of growth regulators on yield

\begin{tabular}{|c|c|c|c|c|c|c|}
\hline \multirow{2}{*}{$\begin{array}{l}\text { Treat- } \\
\text { ment }\end{array}$} & \multicolumn{3}{|c|}{$\begin{array}{c}\text { Concentration-months after } \\
\text { planting }\end{array}$} & \multirow{2}{*}{ Yield $^{1}$} & \multirow{2}{*}{$\begin{array}{l}\text { No. of } \\
\text { cormels/ha }\end{array}$} & \multirow{2}{*}{$\begin{array}{l}\text { Mean } \\
\text { cormel weigh }\end{array}$} \\
\hline & $71 / 2$ & $8^{1 / 4}$ & 9 & & & \\
\hline & $p / m$ & $p / m$ & $p / m$ & $t / h a$ & $10^{3}$ & $g$ \\
\hline Alar & 2000 & 2000 & 2000 & $10.1 \mathrm{a}^{2}$ & $39.6 \mathrm{a}$ & $256 \mathrm{a}$ \\
\hline Cycocel & 2000 & 2085 & 2085 & $11.5 \mathrm{a}$ & $47.6 \mathrm{a}$ & $242 \mathrm{a}$ \\
\hline Ethephon & 1000 & 4093 & 4093 & $10.1 \mathrm{a}$ & $41.8 \mathrm{a}$ & $240 a$ \\
\hline Control & 0 & 0 & 0 & $10.3 \mathrm{a}$ & $44.1 \mathrm{a}$ & $233 \mathrm{a}$ \\
\hline
\end{tabular}

${ }^{1}$ Planted April 10, 1977 and harvested April 11, 1978.

${ }^{2}$ Means in columns followed by the same letter do not differ significantly at the $5 \%$ probability level according to Duncan's multiple range test.

coarse-silty typic Haplaquent of the Perrine marl series. It is a nearly flat, poorly drained soil of a silt loam texture.

The non-replicated exploratory trial 1 was not harvested. Only visual observations were made. In the non-replicated trial 2, an area of approximately $112.9 \mathrm{~m}^{2}$ was harvested (approximately 150 plants) and yield data recorded. Experiment 1 was a randomized complete block design with four replications. Three of the four experimental rows per plot were harvested and yield data statistically analyzed. 


\section{RESULTS AND DISCUSSIONS}

In trial 1, Cycocel initially produced a yellow mottling in the leaf lamina, and 2.5 months after treatment the new leaves were larger and darker green than the control. The dark green color of the leaves agrees with what El-Fowly (3) reported in potato and sweet potato. The tanier leaves in the $1,000 \mathrm{p} / \mathrm{m}$ treatment were larger and more numerous than in the other treatments. In trial 2, the repeated applications of Cycocel at $4,000 \mathrm{p} / \mathrm{m}$ produced fewer but heavier cormels than the control, and yielded about the same as the control. In experiment 1 , repeated applications of Cycocel at 2,000 to $2,085 \mathrm{p} / \mathrm{m}$ tended to produce higher yields than all of the treatments and heavier cormels than the control.

Cycocel is an inhibitor of GA synthesis in plants. Gibberellic acid promotes flowering and weakens apical dominance in tanier, so that axilary leaf systems are produced above the ground. Below the ground, each cormel develops a branching pattern, suggesting that the apical bud of each cormel is no longer dominant. Apparently, the effect of Cycocel is the opposite of the effect of $\mathrm{GA}_{3}$. Cycocel appears to promote the development of only one shoot per plant, and the development of the cormels already initiated at about the time of application. It probably would inhibit the initiation of new cormels, thus allowing the cormels already initiated at the time of application to develop more fully. As a result, if it were applied early enough in the season, the amount of commercial size secondary corms would be increased. Since it promotes an increase in the chlorophyll content of the leaves, and the production of larger leaves of longer leaf duration, more photosynthate would be available for translocation to the main and secondary cormels. However, if Cycocel is applied too early in the season, prior to cormel initiation, it may act to prevent cormel initiation and lead to the production of heavy main corms with little or no secondary cormel production.

In trial 1,8 days after treatment, plants sprayed with 1,500 or $3,000 \mathrm{p} /$ $\mathrm{m}$ Alar looked no different from the controls, while the plants treated with $6,000 \mathrm{p} / \mathrm{m}$ were darker green. At 2.5 months after application, the Alar-treated plants were smaller than the controls. In trial 2, the repeated applications of $4,000 \mathrm{p} / \mathrm{m}$ Alar treatment produced slightly lower yield than Cycocel, and fewer cormels per hectare than the control, but considerably more than the other treatments. The average weight per cormel was more than the control, but less than in the other treatments. In experiment 1 , the repeated application of $2,000 \mathrm{p} / \mathrm{m}$ Alar produced a lower yield and a lower number of secondary cormels per hectare than the control, but resulted in the highest average cormel weight of all the treatments.

The results with the Alar treatments are contradictory. Basically, Alar makes the plant more compact. In trial 2, Alar seemed to promote cormel 
initiation, but not development, while in experiment 1 , it seemed to promote cormel development, but not initiation. In both cases the Alar treatments yielded less than the controls. No conclusions can be made about Alar until further research is carried out.

The Ethrel treatments of trial 1 caused the death of the older leaves, and the subsequent development of new leaves with smaller laminae when fully developed than those of the leaves of the control plants. The proportional length of the petiole with respect to the size of the lamina was greater in these treatments than in the controls. At 2.5 months after treatment, the plants were smaller than in those in the controls. In trial 2, ethephon yielded less and produced fewer secondary cormels per hectare and cormels of heavier average weight each than those of the controls and the other treatments. In experiment 1 , the Ethrel treatments produced the lowest yield, fewer secondary cormels per hectare and a higher average weight per cormel than the control. The plant appearance was the same in both trials and in the experiment. Results indicate that Ethrel by promoting plant senescence, reduced plant foliage. At 4,000 p/ $m$ it was toxic to the leaves. The reduction in foliage was probably associated with less photosynthetic area, which resulted in less photosynthate being produced and translocated to the storage organs. As a result, the Ethrel treatments always yielded less than the control. Since fewer cormels developed, and since the new leaves produced were smaller than the ones prior to treatment, less photosynthate was necessary for leaf production, and more could be translocated to the secondary cormels already initiated. This resulted in cormels of a higher average weight than that in the control, but a lower yield than that of the control.

Gibberellic acid, when applied 2 months prior to harvest at $400 \mathrm{p} / \mathrm{m}$, had no visible effect on the plants. Gibberellic acid treated plants yielded slightly less, and produced fewer secondary cormels of a heavier individual weight than the control. Gibberellic acid treated plants had not flowered or produced axillary leaf systems at harvest. The main and the secondary corms showed no sign of deformity. Apparently, $\mathrm{GA}_{3}$ requires more than 2 months to produce significant visible changes in tanier plants.

\section{RESUMEN}

El efecto de aplicaciones foliares de daminozida (Alar), cloruro de clormequat (Cycocel), y ethephon (Ethrel) se estudió sobre el rendimiento y los componentes de rendimiento de la yautía (Xanthosoma caracu Koch \& Bouché). Las plantas tratadas con Cycocel a concentraciones de 1,000 a 4,000 ppm desarrollaron más follaje y eran de un verde más oscuro que las no asperjadas. No hubo diferencias significativas en rendimiento o en el tamaño medio de los cormelos entre los tratamientos 
y el control. El peso medio del los cormelos fue mayor en las plantas tratadas con Cycocel que en las plantas control. El número de cormelos por hectárea en las plantas tratadas fue menor en la prueba pero mayor que el de las plantas control en el experimento.

\section{LITERATURE CITED}

1. Coursey, D. G. and Haynes, R. H., 1970. Root crops and their potential as food in the tropics, World Crops 22:261-65.

2. Departamento de Agricultura de Puerto Rico, 1978. Ingreso Agrícola de Puerto Rico, 1976-77, 1977-78, Santurce, P. R.

3. El-Fowly, M. M., 1973. Beneficial effects of chlormequat (CCC) on root crops under Egyptian conditions, Proc. 3rd. Int. Symp. Trop. Root Crops Abst. p. 12.

4. Gallatin, M. H., Ballard, J. K., Evans, C. B. Galbery, H. S., Hinton, J. J., Powell, D. P., Truett, E. Watts, W. L., and Willson, G. C., 1958. Soil Survey (detailed reconnaissance) of Dade Country, Florida. USDA Soil Conservation Service and Univ. Fla. Agri. Exp. Stn. Series, 1947, No. 4.

5. Humphries, E. C., 1963. Effects of (2 chloro-ethyl) trimethylammonium chloride on plant growth, leaf area, and net assimilation rate, Ann. Bot. 27:517-32.

6. - and French, S. A. W., 1965. A growth study of sugar beet treated with gibberellic acid and (2-chloroethyl) trimethylammonium chloride (CCC). Ann Appl. Biol. 55:15973.

7. Karikari, S. K., 1973. The effect of defoliation on the yield of cocoyams (Xanthosoma spp. Schott). Proc. 3rd. Int. Symp. Trop. Root Crops Abs. p. 20.

8. USDA and Florida Department of Agriculture and Consumer Services. 1979. Marketing Florida sub-tropical fruits and vegetables, Federal-State Market News Service, Orlando, Fla.

9. Williams, C. N., 1971. Growth and productivity of tapioca (Manihot utilissima) III. Crop ratio, spacing and yield, Exp. Agric, 8:15-23. 